\title{
Perceived Consequences: General or Specific? The Case of Palm Oil-Free Products
}

\author{
Brigitta Plasek $^{1}$, Zoltán Lakner ${ }^{1}$, Katalin Badak-Kerti ${ }^{2}$, , Anikó Kovács ${ }^{2}$ and Ágoston Temesi ${ }^{1, *}$ (i) \\ 1 Department of Food Chain Management, Institute of Economic Sciences, Hungarian University of \\ Agriculture and Life Sciences, 1118 Budapest, Hungary; Plasek.Brigitta@uni-mate.hu (B.P.); \\ Lakner.Zoltan.Karoly@uni-mate.hu (Z.L.) \\ 2 Institute of Food Science and Technology, Hungarian University of Agriculture and Life Sciences, \\ 1118 Budapest, Hungary; Badakne.Kerti.Katalin@uni-mate.hu (K.B.-K.); Kovacs.Aniko94@uni-mate.hu (A.K.) \\ * Correspondence: Temesi.Agoston@uni-mate.hu
}

Citation: Plasek, B.; Lakner, Z.;

Badak-Kerti, K.; Kovács, A.; Temesi, Á. Perceived Consequences: General or Specific? The Case of Palm Oil-Free Products. Sustainability 2021, 13, 3550. https://doi.org/10.3390/su13063550

Academic Editors: Marc A. Rosen and Oliver Meixner

Received: 4 February 2021

Accepted: 19 March 2021

Published: 23 March 2021

Publisher's Note: MDPI stays neutral with regard to jurisdictional claims in published maps and institutional affiliations.

Copyright: (c) 2021 by the authors. Licensee MDPI, Basel, Switzerland. This article is an open access article distributed under the terms and conditions of the Creative Commons Attribution (CC BY) license (https:// creativecommons.org/licenses/by/ $4.0 /)$.
Abstract: Palm oil production and consumption involve several consequences, the perception of which are significant factors that influence consumer behavior. The aim of our research is to explore which health, environmental, or social consequences associated with palm oil influence consumers most in their behavior to avoid palm oil. We examined the three risk types from two approaches: from the viewpoint of generally perceived consequences, and the viewpoint of consequences perceived specifically in relation to palm oil. We collected data through an online consumer survey $(n=336)$, and we applied the method of structural equation modeling to achieve our research aim. According to our results, depending on the approach, all three consequence types influence consumer purchase intentions. Of them, the perceived effects of palm oil on health have the strongest influence on consumption intent, followed by environmental damage caused by palm oil production. The effect of general health consequences show indirect significance through information seeking, which also indicates the importance of the approach to consequence perception. Indirectly or directly, only general social consequences influence purchase intent. Our research suggests that companies developing palm oil-free products could benefit from a label on the product stating their palm oil-free nature.

Keywords: consumer behavior; green products; palm oil free; structural equation modeling; SEM

\section{Introduction}

Palm oil is the plant oil with the highest worldwide consumption [1], and its production shows an increasing trend [2]. Large-scale production and consumption lead to numerous negative environmental and social effects, such as deforestation, biodiversity loss, water pollution, exploitation of growers, and child labor [3]. The expansion of production can be explained by the positive qualities of palm oil, among others its cheapness, versatile application, and effective rate of yield per hectare [4]. In Hungary, the rapid spread of palm oil is partly due to a regulation that took effect in 2013 which limits the maximum quantity of trans fatty acids in food [5]. Following the publication of the regulation, a significant number of producers modified their production technology or replaced their previously used fats with palm oil [6]. Palm oil has a unique composition among fats, therefore it is suitable for many food applications, such as creams, fillings, and margarine [7]. As Berger [8] summarized, there are several reasons for the success and widespread use of palm oil beyond those already mentioned: its cost-effective production, suitability for baking, and its advantage over other vegetable oils in that it can be solid at room temperature, so it does not need to be hydrogenated, and thus it is trans-fatty acid-free. It is due to these qualities that the processed food market accounts for about $72 \%$ of palm oil production [9]. 
Although palm oil possesses several positive characteristics, there are still products on the food market that communicate their palm oil-free nature to the consumers. The question arises if palm oil is an ingredient with many beneficial features from several aspects, what is it that still encourages consumers to purchase palm oil-free products, and whether the business practice to communicate palm oil-freeness can be justified. To date, there are several so far unresearched questions related to consumer familiarity with and attitudes to palm oil [10], but it is obvious that consumers possess little knowledge about palm oil-related issues [11-14].

The palm oil industry creates negative associations in consumers [15], thus consumers may have formed unique negative attitudes and beliefs towards such products, which can affect their purchasing behavior [11]. We can identify three different risk types associated with palm oil: impacts on the environment, health, and society [16].

Previous research on the health effects of palm oil has investigated its contribution to the development of coronary heart disease; however, compared to other oils, the effect of palm oil on cholesterol levels can be considered neutral [17]. Several studies point out the health effects of palm oil as the main factor influencing its consumption $[18,19]$. According to the results of Verneau and colleagues, it is the alleged detrimental health effects of palm oil consumption that motivate consumers to avoid products that contain it. It has become a widely held belief that palm oil-free products are healthier than those containing palm oil [11,20], even though there is no scientific evidence that palm oil is harmful to health [11]. On the other hand, Aguiar and colleagues [15] argue that consumers may consider palm oil a natural ingredient, and as such, it may contribute to a healthy life.

In recent years, several studies have investigated different aspects of consumer behavior related to sustainability (e.g., [21-23]) and numerous review articles have summarized what we have learned so far (e.g., [24-26]). Sustainability and environmental risks are also an issue highlighted in palm oil-related consumer research. Guadalupe et al. [27] maintain that the environmental risks accompanying palm oil production are perceived in both the importing and the producing countries. In their comparison based on Spanish and Peruvian samples, respondents from both countries viewed the environmental impacts of palm oil production negatively [27]. The unregulated expansion of palm oil cultivation poses a serious threat to biodiversity in Southeast Asia [28]. Results show that the more consumers are familiar with this ingredient and the environmental impact of its production, the more they intend to reduce consumption [14], and the more they consider palm oil-free products more sustainable [11].

The third consequence type, the possible negative social effects (e.g., exploitation, child labor, etc.) are less known to consumers, and thus they are less worried about them than about the other two risks [16]. At the same time, palm oil consumption indirectly results in job opportunities in the producing countries, which may thus also develop positive attitudes in the consumer in that they help the economies of the producing countries by consuming palm oil [15].

Because of the harmful effects perceived by consumers of palm oil, earlier research was aimed at reducing or replacing palm oil in food [14,29]. At the same time, researchers rightly ponder whether consumers pay attention to this product ingredient $[12,15,27,30,31]$ and whether it influences purchasing or consumer behavior [13]. Due to the functionality of palm oil, it is a technological challenge to the food industry to replace it with other fats. The commercially available alternatives for palm oil are based on liquid oils, fully hydrogenated fats, and different exotic fats like shea butter. Blending these ingredients could be an opportunity for substitution [32].

\section{Aim of Research}

The aim of our research is to explore how much Hungarian respondents know about palm oil, and how they perceive its impact on health, the environment, and the societies of producing countries. The many technological advantages of palm oil notwithstanding, a niche market has emerged for palm oil-free products, presumably due to the perceived 
negative effects of palm oil. We also strive to identify the consequence factor with the strongest influence on consumers to purchase palm oil-free products. To examine this latter aim, Verneau et al. [19] have already modeled consumer behavior with the statements we applied, and their research included more indirect relations than what we explored in our current study. That study did not, however, investigate personal beliefs. That is, what consumers specifically think about the risks associated with palm oil, how they perceive their significance. Verneau et al. acknowledged this omission and indicated it as a limitation of their study. By examining consequences and risk factors in our model in general, and in relation to palm oil in particular, we sought to answer whether the intention to purchase palm oil-free products was influenced by problems perceived in general or by perceptions related to palm oil in particular.

\subsection{Hypotheses}

\subsubsection{Perceived Consequences and Their Impact on Purchase Intent}

Sodano et al. [16] identified three risk types (health, environmental and social) associated with products containing palm oil. Further research has explored consumer perceptions of these risk types from different perspectives, and how these factors influence purchase intent $[3,11,18-20,30,33,34]$. Numerous studies have examined specific problems arising during the process of palm oil production $[3,11,20,30,33]$ and only a few were based on the impact of risks perceived in general $[18,19,34]$. This duality can result in different outcomes for specific consequences. Our first hypothesis was based on this assumption.

Hypothesis 1 (H1). All three consequence factors, both generally and specifically, directly and significantly influence purchase intent for palm oil-free products.

Little research has been done on consumer perceptions of the health effects of palm oil [20]. At the same time, many scholars have investigated the perceptions of its environmental effects $[3,14,30,31,33-35]$. Some studies compare the effects of these consequences. Some results show that environmental consequences have a bigger influence on consumer perceptions [18], while other results show that health consequences do, even if only indirectly [19]. Yet others show that the two consequence types influence consumers to a similar extent [12,16].

Several studies have pointed out that consumer knowledge of palm oil is scant [11-14], and mostly associated with its health and environmental consequences. Meanwhile, consumers have difficulty perceiving social risk, as it carries both positive (e.g., employment, income generation) and negative (e.g., conflicts, housing conditions) effects [36]. According to the results of Sodano et al. [16], of the three risk types, social risk worries consumers the least.

Related to the perceived consequences, we formed the following two hypotheses:

Hypothesis 2 (H2). Of the three consequence factors, health consequences motivate consumers the most to purchase palm oil-free products, followed by environmental consequences, and finally social consequences.

Hypothesis 3 (H3). Health and environmental consequences primarily influence purchase intent directly as perceived in association with palm oil, while social consequences do so in association with general consequence perception.

2.1.2. The Relationship between Information Seeking and Purchase Intent for Palm Oil-Free Products

The demand for information and information-seeking are significantly determined by the perception of specific risks [37]. In relation to health risks, in some scenarios, responsive individuals are more open to seeking information, whereas "avoidant individuals" are less open [38]. The relationship between the perception of environmental risk and seeking 
information is more tangible for people who are more exposed to a specific environmental problem, such as a flood [39]. For more eco-friendly products, providing information is essential to increasing purchase intent [40]. Available information also plays an important role in the assessment of the negative and positive impacts of social risk [36].

Information, especially negative information, and emerging consumer beliefs strongly influence purchase intent [12]. The results of the model of Verneau et al. [19] demonstrated that information seeking directly influences consumers in their purchase intent, more so than the consequences.

Hypothesis 4 (H4). Information seeking significantly and positively influences purchase intent for palm oil-free products.

Hypothesis 5 (H5). Perception of the consequences associated with palm oil influences consumers to seek information about palm oil more than general risk perception.

Figure 1 illustrates the conceptual model.

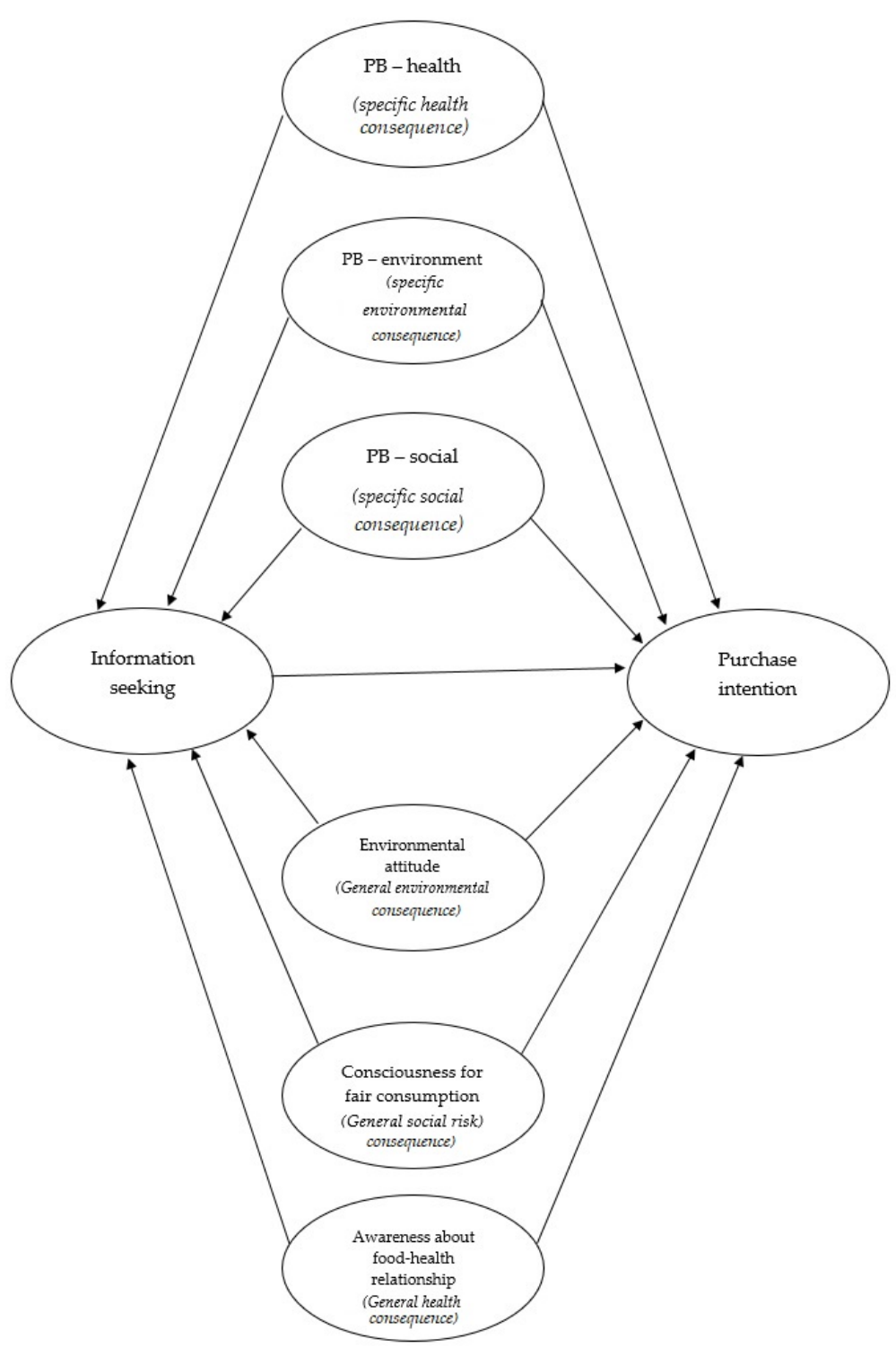

Figure 1. Conceptual framework (PB-Personal beliefs about palm oil). 


\section{Materials and Methods}

In this study, we used a quantitative research tool, namely consumer surveys. Hungarian respondents were contacted through online social media to complete the survey, so completing it was voluntary. Respondents gave written consent for their answers to be analyzed. The surveys were administered from 15 May 2020 through 1 June 2020. Over this period, we received answers from 336 respondents.

In the first part of the survey, we used Lange and Coreman's [14] "knowledge scale" to assess respondents' familiarity with the environmental, health, and social impacts of palm oil. In this context, in the second part of the survey, we asked respondents to rate on a 1-5-point Likert scale how healthy they considered three food products whose palm oil content was explicitly pointed out to them in the questions to be, how environmentally harmful they considered products that contain palm oil to be, and how harmful they thought palm oil production was to the societies of palm oil-producing countries. In the third part of the survey, we explored attitudes towards palm oil with the help of the scales devised by Capecchi et al. [18]. Of the 41 items they specified in the scale, we used 31 statements relevant to our research. Finally, we collected respondents' demographic and other information, as summarized in Table 1.

Table 1. Respondents' demographic and other data $(n=336)$.

\begin{tabular}{|c|c|c|}
\hline Variables & & $\begin{array}{c}\text { Sample Composition } \\
\%\end{array}$ \\
\hline \multirow{2}{*}{ Gender } & Male & 21.4 \\
\hline & Female & 78.6 \\
\hline \multirow{5}{*}{ Age group } & $18-25$ yrs & 18.8 \\
\hline & $26-35$ yrs & 23.2 \\
\hline & $36-45$ yrs & 25.3 \\
\hline & $46-55$ yrs & 19.6 \\
\hline & 56 yrs and older & 13.1 \\
\hline \multirow{4}{*}{ Completed education } & $\begin{array}{c}\text { Max. } 8 \text { yrs of elementary } \\
\text { school }\end{array}$ & 3.9 \\
\hline & Vocational school & 16.1 \\
\hline & High school certificate & 37.8 \\
\hline & Tertiary education & 42.3 \\
\hline \multirow{4}{*}{ Residence } & Capital & 26.2 \\
\hline & Greater capital area & 8.6 \\
\hline & $\begin{array}{c}\text { Countryside town (not in the } \\
\text { greater area) }\end{array}$ & 50 \\
\hline & $\begin{array}{l}\text { Village/settlement outside of } \\
\text { the greater area }\end{array}$ & 15.2 \\
\hline \multirow{5}{*}{ Perception of income } & Very tight & 7.4 \\
\hline & Tight & 18.2 \\
\hline & Average & 51.5 \\
\hline & Good & 20.5 \\
\hline & Very good & 2.4 \\
\hline \multirow{3}{*}{$\begin{array}{l}\text { Person in the household } \\
\text { responsible for buying } \\
\text { groceries }\end{array}$} & Respondent & 44.6 \\
\hline & Other & 7.1 \\
\hline & Shared & 48.2 \\
\hline \multirow{5}{*}{ Household size } & 1 person & 7.4 \\
\hline & 2 persons & 32.7 \\
\hline & 3 persons & 28.0 \\
\hline & 4 persons & 17.0 \\
\hline & 5 or more persons & 14.9 \\
\hline
\end{tabular}




\section{Data Analysis}

To measure attitude statements and knowledge level, we used descriptive statistical methods.

For the structural equations modeling, we worked with SmartPLS software [41]. To construct the conceptual model, we used the attitude statements mentioned earlier. The points of the model were designed based on the categories applied by Capecchi et al. [18]. The focus was on the category "purchase intention," which we measured with three statements. Since we constructed a reflective model, we used the consistent PLS algorithm and the consistent bootstrapping methods in our calculations. Table 2 summarizes the elements of the model.

Table 2. Items and constructs (based on Capecchi et al. [18]).

\begin{tabular}{c} 
Construct and Indicators \\
\hline Purchase intention \\
\hline When I have a choice, I buy products without palm oil \\
I am willing to pay more for products without palm oil \\
I always tell my friends to buy products without palm oil \\
Personal beliefs-environment
\end{tabular}

Reducing palm oil production contributes to curbing deforestation

Reducing palm oil production can help counteract the effects of climate change

Reducing palm oil production can slow down the extinction of many animal species

$$
\text { Personal beliefs-health }
$$

Consumption of refined palm oil can be harmful to human health

Consumption of refined palm oil can promote the onset of cancer

Consumption of refined palm oil can promote the onset of cardiovascular disease

$$
\text { Personal beliefs—social }
$$

Reducing palm oil production contributes to counteracting exploitation of child labour

Reducing palm oil production contributes to counteracting abuses against plantation workers

Reducing palm oil production contributes to improving working conditions of peasant families in all producing Countries

\section{Environmental attitude}

Melting of the polar ice caps may result in a flooding of shores and islands.

Poisonous metals are introduced into the food chain, for instance, via ground water

The world climate will probably massively change if $\mathrm{CO}_{2}$ continues to be emitted into the atmosphere in as huge amounts as it is now

Over the next several decades, thousands of species will become extinct

Pollution generated in one country harms people all over the world

Consciousness for fair consumption

I only buy a product if I believe that in its production the workers' rights were adhered to

I only buy a product if I believe that in its production no worker was subjected to forced labour

I only buy a product if I believe that in its production no illegal child labour was involved

I only buy a product if I believe that in its production workers were not discriminated

I only buy a product if I believe that in its production the working conditions complied with the international labour standards I only buy a product if I believe that in its production the workers were treated fairly or were fairly compensated

Awareness about food-health relationship

Food plays an important role in keeping me in good health

I know which food is healthy for me

My health is determined by the food I eat

I feel I am eating in a healthier way now as compared to three years ago

\section{Information seeking}

Over the last six months I have been looking for information on palm oil

I always talk to my friends/relatives about the effects of palm oil consumption

If I read news about palm oil, I try to study it in depth

I know well which brands have eliminated palm oil from their products 


\section{Results}

\subsection{Respondents' Knowledge about Palm Oil}

In the first part of the survey, we used Lange and Coreman's [14] "knowledge scale" to assess how much respondents think they are aware of the effects of palm oil on the environment, health, and the societies of the producing countries.

The results are summarized in Table 3.

Table 3. Respondents' knowledge about palm oil $(n=336)$.

\begin{tabular}{cccc}
\hline & Impact on Health & Impact on the Environment & Impact on Society \\
\hline \multicolumn{3}{c}{ Knowledge Scale } \\
\hline Not at all & 16.1 & $\%$ & $\%$ \\
Barely & 28.3 & 15.5 & 25.3 \\
To some extent & 38.4 & 19.0 & 27.7 \\
Quite well & 13.7 & 37.8 & 32.7 \\
Very well & 3.6 & 21.1 & 12.2 \\
\hline
\end{tabular}

The results in Table 3 clearly show that most respondents were not at all, barely, or only to some extent aware of the effects of palm oil on the environment, society, and health. Regarding the three consequence types, a higher proportion of respondents thought that they were not at all aware of social consequences, while they thought they were the most aware of the impacts on the environment.

\subsection{Perception of the Effects of Palm Oil on Health, the Environment, and Society}

We examined perceptions of the effects of palm oil on health through products that contain it because respondents do not encounter palm oil by itself, but they do encounter products containing it. We asked them how healthy they considered palm oil-containing bakery, chocolate, and margarine goods to be, as consumers know that palm oil is commonly used for their production [34]. We examined the perceptions of the effects on the environment and society with one question each. The results of these questions are summarized in Table 4.

Table 4. Perception of the effects of palm oil-containing products on health, society, and the environment $(n=336)$.

\begin{tabular}{|c|c|c|c|c|c|}
\hline & \multicolumn{3}{|c|}{ Effect on Health } & Effect on the Environment & Effect on Society \\
\hline \multicolumn{6}{|c|}{ How concerned are you about the consequences of palm oil containing products? } \\
\hline & Margarine & Bakery & Chocolate & & \\
\hline & $\%$ & $\%$ & $\%$ & & \\
\hline Not at all & 25.9 & 20.8 & 23.5 & 16.4 & 17.0 \\
\hline Barely & 21.7 & 26.2 & 23.5 & 14.0 & 13.7 \\
\hline $\begin{array}{l}\text { To some } \\
\text { extent }\end{array}$ & 27.4 & 27.4 & 25.6 & 16.7 & 29.8 \\
\hline Quite much & 14.0 & 17.0 & 17.3 & 25.3 & 25.0 \\
\hline Very much & 11.0 & 8.6 & 10.1 & 27.7 & 14.6 \\
\hline
\end{tabular}

Our results show that nearly half of the respondents did not consider palm oilcontaining products to be healthy at all, or considered them to rather not healthy, and only one in four respondents considered palm oil-containing products to be healthy.

Of the three consequences we examined, respondents were the most divided on the perception of the effects of palm oil production on society, as they could not assess whether such a risk existed or not.

Of the three consequence types, respondents considered the effect on the environment to be the most harmful. Despite low consumer knowledge compared to the other two consequence types, more than $50 \%$ of respondents thought the effect on the environment to be rather or completely harmful. 


\subsection{Attitudes Influencing Purchase Intent for Palm Oil-Containing Products-Structural Equation Modeling}

\subsubsection{Construct Reliability and Validity of the Model}

We constructed the model with the help of the attitude statements used in the quantitative research phase. The reliability of the model is supported by several indices, such as Cronbach's alpha, composite reliability (CR), average variance extracted (AVE), and the items' outer loadings. The values of Cronbach's alpha consistently exceed 0.7 , as recommended by the literature [42], and our lowest value was 0.869 . The values of composite reliability must also exceed 0.7 [43], in our study they fell between 0.872 and 0.969 . The values of the average variance extracted (AVE) were between 0.640 and 0.884 , also conformed to the expected minimum of 0.5 [44]. The outer loading values were between 0.680 and 0.990. Bagozzi and Yi [45] state the expected value to be over 0.7. In social research, this value often happens to be lower than 0.7 [46]. Hair et al. [47] opine that deleting the indices with an outer loading of 0.40 through 0.70 is necessary if it results in an increase in composite reliability. We examined the model without the two statements in question, but the composite reliability values increased only by one-thousandth. Thus, we kept the two statements in the model. Overall, based on the indicators presented so far, the reliability of our model can be considered good.

Table 5 summarizes the construct reliability and validity values.

Table 5. Construct reliability and validity.

\begin{tabular}{|c|c|}
\hline Construct and Indicators & Outer Loading \\
\hline \multicolumn{2}{|l|}{ Purchase intention $(\mathrm{CA}=0.869, \mathrm{CR}=0.872, \mathrm{AVE}=0.696)$} \\
\hline When I have a choice, I buy products without palm oil & 0.881 \\
\hline I am willing to pay more for products without palm oil & 0.867 \\
\hline I always tell my friends to buy products without palm oil & 0.749 \\
\hline \multicolumn{2}{|l|}{ Personal beliefs-environment $(\mathrm{CA}=0.958, \mathrm{CR}=0.958, \mathrm{AVE}=0.884)$} \\
\hline Reducing palm oil production contributes to curbing deforestation & 0.900 \\
\hline Reducing palm oil production can help counteract the effects of climate change & 0.959 \\
\hline Reducing palm oil production can slow down the extinction of many animal species & 0.960 \\
\hline \multicolumn{2}{|l|}{ Personal beliefs-health $(\mathrm{CA}=0.939, \mathrm{CR}=0.938, \mathrm{AVE}=0.835)$} \\
\hline Consumption of refined palm oil can be harmful to human health & 0.952 \\
\hline Consumption of refined palm oil can promote the onset of cancer & 0.901 \\
\hline Consumption of refined palm oil can promote the onset of cardiovascular disease & 0.888 \\
\hline \multicolumn{2}{|l|}{ Personal beliefs—social $(\mathrm{CA}=0.901, \mathrm{CR}=0.908, \mathrm{AVE}=0.772)$} \\
\hline Reducing palm oil production contributes to counteracting exploitation of child labour & 0.973 \\
\hline $\begin{array}{c}\text { Reducing palm oil production contributes to counteracting abuses against } \\
\text { plantation workers }\end{array}$ & 0.946 \\
\hline $\begin{array}{l}\text { Reducing palm oil production contributes to improving working conditions of peasant } \\
\text { families in all producing Countries }\end{array}$ & 0.688 \\
\hline \multicolumn{2}{|l|}{ Environmental attitude $(\mathrm{CA}=0.922, \mathrm{CR}=0.921, \mathrm{AVE}=0.702)$} \\
\hline Melting of the polar ice caps may result in a flooding of shores and islands. & 0.890 \\
\hline Poisonous metals are introduced into the food chain, for instance, via ground water & 0.792 \\
\hline $\begin{array}{l}\text { The world climate will probably massively change if } \mathrm{CO}_{2} \text { continues to be emitted into the } \\
\text { atmosphere in as huge amounts as it is now }\end{array}$ & 0.734 \\
\hline Over the next several decades, thousands of species will become extinct & 0.891 \\
\hline Pollution generated in one country harms people all over the world & 0.869 \\
\hline \multicolumn{2}{|l|}{ Consciousness for fair consumption $(\mathrm{CA}=0.969, \mathrm{CR}=0.969, \mathrm{AVE}=0.838)$} \\
\hline I only buy a product if I believe that in its production the workers' rights were adhered to & 0.946 \\
\hline $\begin{array}{l}\text { I only buy a product if I believe that in its production no worker was subjected to } \\
\text { forced labour }\end{array}$ & 0.990 \\
\hline I only buy a product if I believe that in its production no illegal child labour was involved & 0.946 \\
\hline I only buy a product if I believe that in its production workers were not discriminated & 0.869 \\
\hline
\end{tabular}


Table 5. Cont.

\begin{tabular}{|c|c|}
\hline Construct and Indicators & Outer Loading \\
\hline $\begin{array}{l}\text { I only buy a product if I believe that in its production the working conditions complied } \\
\text { with the international labour standards }\end{array}$ & 0.838 \\
\hline $\begin{array}{l}\text { I only buy a product if I believe that in its production the workers were treated fairly or } \\
\text { were fairly compensated }\end{array}$ & 0.894 \\
\hline \multicolumn{2}{|l|}{ Awareness about food-health relationship $(\mathrm{CA}=0.888, \mathrm{CR}=0.886, \mathrm{AVE}=0.662)$} \\
\hline Food plays an important role in keeping me in good health & 0.746 \\
\hline I know which food is healthy for me & 0.893 \\
\hline My health is determined by the food I eat & 0.782 \\
\hline I feel I am eating in a healthier way now as compared to three years ago & 0.826 \\
\hline \multicolumn{2}{|l|}{ Information seeking $(\mathrm{CA}=0.876, \mathrm{CR}=0.876, \mathrm{AVE}=0.640)$} \\
\hline Over the last six months I have been looking for information on palm oil & 0.745 \\
\hline I always talk to my friends/relatives about the effects of palm oil consumption & 0.893 \\
\hline If I read news about palm oil, I try to study it in depth & 0.783 \\
\hline I know well which brands have eliminated palm oil from their products & 0.827 \\
\hline
\end{tabular}

(CA = Cronbach's alpha, $\mathrm{CR}=$ composite reliability, AVE = average variance extracted).

\subsubsection{Model Fit, Discriminant Validity and Explanatory Power of the Model}

To examine the fit of the model, we present the standardized root-mean square residual (SRMR) and the normed fit index (NFI) values. Hu and Bentler [48] state that an SRMR value lower than 0.08 shows a good model fit, as does an NFI value higher than 0.95 . However, these numbers were not applied as as cutoff values, as the values of these indicators can vary depending on several factors [49]. According to our results, the model fit was adequate (SRMR $=0.053, \mathrm{NFI}=0.816$ ). The low NFI value can be attributed to the relatively small sample, which often causes this index to underestimate the fit [50].

To measure discriminant validity, we present two methods, the Fornell-Larcker test (Table 6) and the heterotrait-monotrait (HTMT) criterion (Table 7).

According to the Fornell-Larcker test, a specific latent construct must better explain the variance of its own index than the variance of any other latent construct [51]. As the results in Table 6 attest, this was true for our model.

The results in Table 7-HTMT criterion-also confirmed that discriminant validity had been established, as the values obtained were all below 0.9 [52].

The explanatory power of the model is illustrated by the values of $R^{2}$ and adjusted $R^{2}$, as summarized in Table 8 . The model explains $59.7 \%$ of the purchase intention (adjusted $\mathrm{R}^{2}=0.596$ ). The model constructed by Verneau et al. [19] explained $46 \%$ of purchase intention, so by expanding on it, we achieved a $14 \%$ increase in explanatory power.

\subsubsection{Presenting the Results of the Structural Model}

To determine the significance level of each correlation and the values of $\mathrm{T}$ and $\mathrm{f}^{2}$, we used bootstrapping (number of subsamples $=5000$ ). Table 9 and Figure 2 show the results.

Based on our model, and similar to the study by Verneau et al. [19], informationseeking had the strongest influence $(\mathrm{H} 4, \mathrm{~B}=0.340, p=0.000)$ on the consumer behavior of Hungarian respondents in avoiding palm oil. But this effect was not outstandingly high compared to other direct effects. 
Table 6. Fornell-Larcker test of discriminant validity

\begin{tabular}{|c|c|c|c|c|c|c|c|c|}
\hline & $\begin{array}{c}\text { Awareness about } \\
\text { Food-Health Relationship }\end{array}$ & $\begin{array}{l}\text { Consciousness for Fair } \\
\text { Consumption }\end{array}$ & $\begin{array}{l}\text { Environmental } \\
\text { Attitude }\end{array}$ & Information Seeking & Purchase Intention & $\begin{array}{c}\text { Personal } \\
\text { Beliefs-Environment }\end{array}$ & $\begin{array}{c}\text { Personal } \\
\text { Beliefs-Health }\end{array}$ & $\begin{array}{c}\text { Personal } \\
\text { Beliefs-Social }\end{array}$ \\
\hline $\begin{array}{l}\text { Awareness about } \\
\text { food-health } \\
\text { relationship }\end{array}$ & 0.814 & & & & & & & \\
\hline $\begin{array}{l}\text { Consciousness for fair } \\
\text { consumption }\end{array}$ & 0.459 & 0.915 & & & & & & \\
\hline Environmental attitude & 0.610 & 0.415 & 0.838 & & & & & \\
\hline $\begin{array}{l}\text { Information seeking } \\
\text { Purchase intention }\end{array}$ & $\begin{array}{l}0.473 \\
0.526\end{array}$ & $\begin{array}{l}0.426 \\
0.462\end{array}$ & $\begin{array}{l}0.264 \\
0.434\end{array}$ & $\begin{array}{l}0.800 \\
0.584\end{array}$ & 0.834 & & & \\
\hline $\begin{array}{l}\text { Personal } \\
\text { beliefs-environment }\end{array}$ & 0.520 & 0.358 & 0.670 & 0.322 & 0.606 & 0.940 & & \\
\hline $\begin{array}{l}\text { Personal } \\
\text { beliefs-Chealth }\end{array}$ & 0.399 & 0.317 & 0.492 & 0.280 & 0.605 & 0.697 & 0.914 & \\
\hline
\end{tabular}

Table 7. Discriminant validity: heterotrait-monotrait (HTMT) criterion.

\begin{tabular}{|c|c|c|c|c|c|c|c|c|}
\hline & $\begin{array}{c}\text { Awareness about } \\
\text { Food-Health Relationship }\end{array}$ & $\begin{array}{c}\text { Consciousness for Fair } \\
\text { Consumption }\end{array}$ & $\begin{array}{c}\text { Environmental } \\
\text { Attitude }\end{array}$ & Information Seeking & Purchase Intention & $\begin{array}{c}\text { Personal } \\
\text { Beliefs-Environment }\end{array}$ & $\begin{array}{c}\text { Personal } \\
\text { Beliefs-Health }\end{array}$ & $\begin{array}{c}\text { Personal } \\
\text { Beliefs-Social }\end{array}$ \\
\hline $\begin{array}{l}\text { Awareness about } \\
\text { food-health } \\
\text { relationship }\end{array}$ & & & & & & & & \\
\hline $\begin{array}{l}\text { Consciousness for fair } \\
\text { consumption }\end{array}$ & 0.461 & & & & & & & \\
\hline Environmental attitude & 0.614 & 0.414 & & & & & & \\
\hline $\begin{array}{l}\text { Information seeking } \\
\text { Purchase intention }\end{array}$ & $\begin{array}{l}0.466 \\
0.525\end{array}$ & $\begin{array}{l}0.426 \\
0.462\end{array}$ & $\begin{array}{l}0.259 \\
0.429\end{array}$ & 0,589 & & & & \\
\hline $\begin{array}{c}\text { Purchase intention } \\
\text { Personal } \\
\text { beliefs-environment }\end{array}$ & $\begin{array}{l}0.525 \\
0.523\end{array}$ & $\begin{array}{l}0.462 \\
0.356\end{array}$ & $\begin{array}{l}0.429 \\
0.670\end{array}$ & 0.317 & 0.603 & & & \\
\hline $\begin{array}{l}\text { Personal } \\
\text { Pelta }\end{array}$ & 0.400 & 0.315 & 0.491 & 0.276 & 0.604 & 0.696 & & \\
\hline
\end{tabular}


Table 8. Results illustrating the explanatory power of the model.

\begin{tabular}{ccc}
\hline & $\mathbf{R}^{\mathbf{2}}$ & Adjusted $\mathbf{R}^{\mathbf{2}}$ \\
\hline Purchase intention & 0.606 & 0.597 \\
Information seeking & 0.298 & 0.285 \\
\hline
\end{tabular}

Table 9. The results of the structural equation modeling.

\begin{tabular}{|c|c|c|c|c|c|c|c|c|}
\hline \multirow{2}{*}{ Relation } & \multicolumn{2}{|c|}{ Direct Effect } & \multicolumn{2}{|c|}{ Indirect Effect } & \multicolumn{2}{|c|}{ Total Effect } & \multirow{2}{*}{ Cohen's $f^{2}$} & \multirow{2}{*}{ Supported? } \\
\hline & Effect Size & T Value & Effect Size & T Value & Effect Size & T Value & & \\
\hline $\begin{array}{l}\text { Awareness about food-health } \\
\text { relationship } \rightarrow \text { Information seeking }\end{array}$ & $0.381 * *$ & 4.586 & - & - & 0.381 ** & 4.586 & 0.116 & Yes \\
\hline $\begin{array}{l}\text { Awareness about food-health } \\
\text { relationship } \rightarrow \text { Purchase intention }\end{array}$ & $0.117^{\text {n.s. }}$ & 1.509 & $0.130 * *$ & 3.494 & $0.246^{* *}$ & 3.212 & 0.017 & No \\
\hline $\begin{array}{l}\text { Consciousness for fair consumption } \rightarrow \\
\text { Information seeking }\end{array}$ & $0.268 * *$ & 4.138 & - & - & $0.268^{* *}$ & 4.138 & 0.077 & Yes \\
\hline $\begin{array}{c}\text { Consciousness for fair consumption } \rightarrow \\
\text { Purchase intention }\end{array}$ & $0.118^{*}$ & 2.123 & 0.091 ** & 3.209 & $0.209 * *$ & 3.548 & 0.025 & Yes \\
\hline $\begin{array}{c}\text { Environmental attitude } \rightarrow \text { Information } \\
\text { seeking }\end{array}$ & $-0.184^{*}$ & 2.013 & - & - & $-0.184^{*}$ & 2.013 & 0.021 & Yes \\
\hline $\begin{array}{c}\text { Environmental attitude } \rightarrow \text { Purchase } \\
\text { intention }\end{array}$ & $-0.084^{\text {n.s. }}$ & 1.058 & $-0.062^{\text {n.s. }}$ & 1.943 & $-0.146^{\text {n.s. }}$ & 1.833 & 0.008 & No \\
\hline $\begin{array}{c}\text { Information seeking } \\
\text { intention }\end{array} \rightarrow$ Purchase & $0.340 * *$ & 5.474 & - & - & $0.340^{* *}$ & 5.474 & 0.206 & Yes \\
\hline $\begin{array}{l}\text { Personal beliefs-environment } \rightarrow \\
\text { Information seeking }\end{array}$ & $0.082^{\text {n.s. }}$ & 0.723 & - & - & $0.082^{\text {n.s. }}$ & 0.723 & 0.003 & No \\
\hline $\begin{array}{l}\text { Personal beliefs-environment } \rightarrow \\
\text { Purchase intention }\end{array}$ & $0.261^{* *}$ & 2.699 & $0.028^{\text {n.s. }}$ & 0.708 & $0.289 * *$ & 2.754 & 0.046 & Yes \\
\hline $\begin{array}{c}\text { Personal beliefs_-health } \rightarrow \text { Information } \\
\text { seeking }\end{array}$ & $0.040^{\text {n.s. }}$ & 0.508 & - & - & $0.040^{\text {n.s. }}$ & 0.508 & 0.001 & No \\
\hline $\begin{array}{c}\text { Personal beliefs-health } \rightarrow \text { Purchase } \\
\text { intention }\end{array}$ & $0.308^{* *}$ & 4.291 & $0.014^{\text {n.s. }}$ & 0.497 & 0.322 ** & 4.236 & 0.108 & Yes \\
\hline $\begin{array}{c}\text { Personal beliefs—social } \\
\text { seeking }\end{array} \rightarrow$ Information & $0.050^{\text {n.s. }}$ & 0.460 & - & - & $0.050^{\text {n.s. }}$ & 0.460 & 0.001 & No \\
\hline $\begin{array}{c}\text { Personal beliefs-social } \\
\text { intention }\end{array} \rightarrow$ Purchase & $-0.032^{\text {n.s. }}$ & 0.370 & $0.017^{\text {n.s. }}$ & 0.447 & $-0.015^{\text {n.s. }}$ & 0.165 & 0.001 & No \\
\hline
\end{tabular}

${ }^{*} p<0.05,{ }^{* *} p<0.01$, n.s. - non-significant). Model fit: $\mathrm{SRMR}=0.053, \mathrm{NFI}=0.816$

We hypothesized that all three consequences had a direct and significant effect on purchase intent (H1). This was supported by the model, but the nature of consequence perception greatly influences the effect of consequences on purchase intent. In our second hypothesis, we hypothesized that purchase intention was influenced the most by the health consequences, followed by the environmental consequences, and the social consequences. This was supported by our results. Whereas the environmental $(B=0.261, p=0.007)$ and health consequences $(B=0.308, p=0.000)$ showed a significant effect in the context of the consequences perceived in relation to palm oil, the social consequences did so in connection with issues related to the societal problems perceived in general $(B=0.118, p=0.034)$. However, if we examine them in general, neither the health nor the environmental consequences showed a significant effect. Thus, our third hypothesis was confirmed.

In addition to direct effects, we also examined the indirect effects of the consequence factors in our model perceived both in general and specifically in association with palm oil via information-seeking as mediating variable. We assessed the nature of the mediation effect based on the types demonstrated by Hair et al. [47]. For health consequences perceived in general, indirect-only mediation exists. The results summarized in Table 9 show that the direct effect was not significant, but the indirect effect was $(B=0.130$, $p=0.000$ ). Thus, the perception of the health consequences of food consumption did not directly influence the purchase intent of palm oil-free products but did influence respondents' information-seeking on palm oil. Through this mediating variable, we already experienced a significant effect (total effect $\beta=0.246, p=0.001$ ). However, for attitudes 
related to general environmental outcomes, there was no significant effect even in this case, as neither the direct nor the indirect effect $(B=-0.062, p=0.055)$ was significant. The effect of non-palm oil-specific social outcomes was intensified by the mediating variable, thus complementary mediation exists. However, the thusly emerging total effect was no longer so important $(B=0.209, p=0.000)$ as in the case of the health risks $(B=0.246$, $p=0.001$ ). In the case of the environmental and health consequence perceived in relation to palm oil, we found direct-only nonmediation, as there was a significant effect only for the direct relationship, and for the social consequences, no significant effect was found at all (no-effect nonmediation). Whereas two of the risks perceived in general did not have a direct significant effect on purchase intent, they do have one through information seeking. Problems specifically associated with palm oil only directly influenced purchase intent for palm oil-free products, and information-seeking did not mediate it for any of the risks.

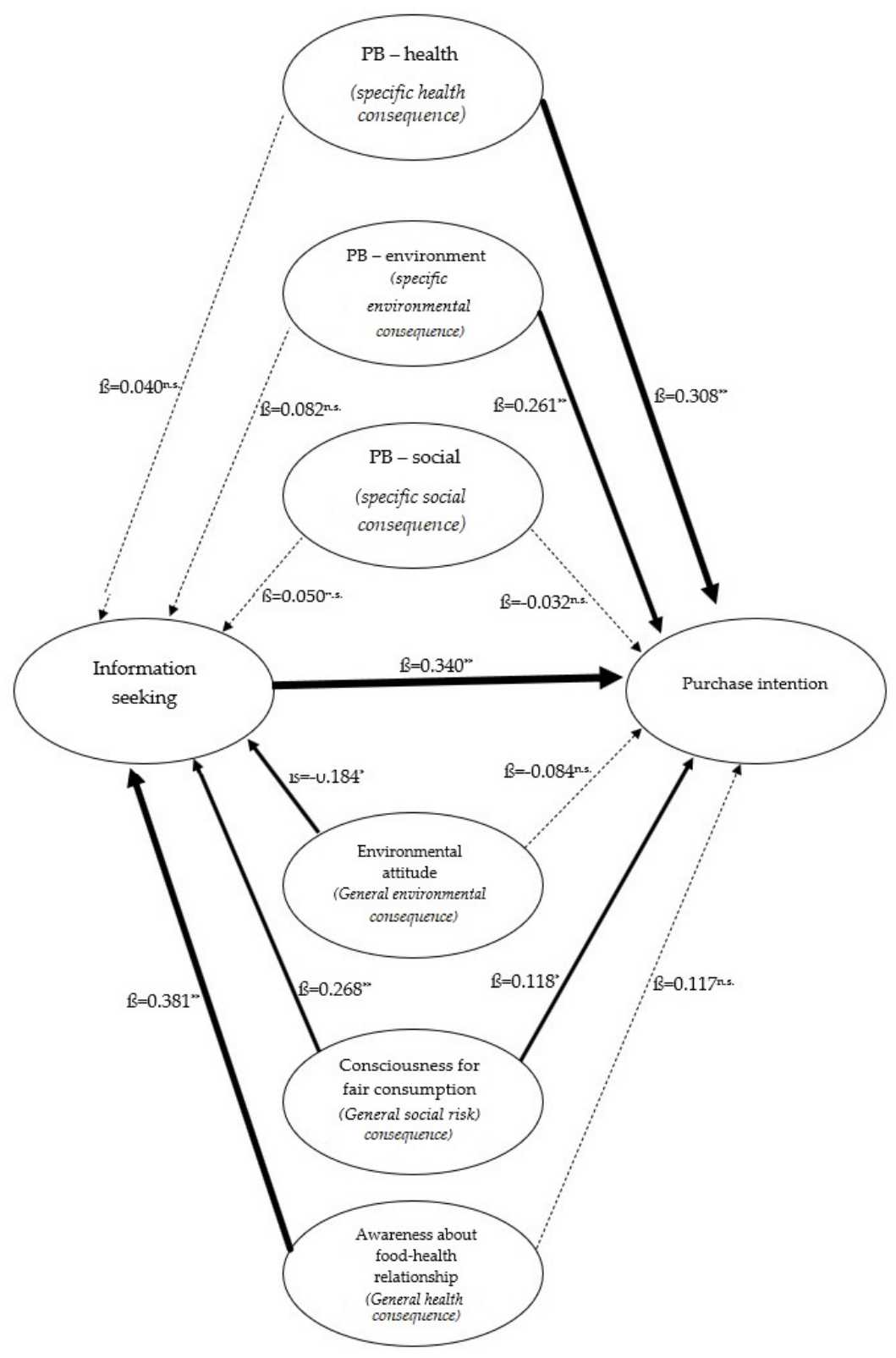

Figure 2. The results of structural equation modeling-direct effect sizes. $\left({ }^{*} p<0.05,{ }^{* *} p<0.01\right.$, n.s.-non-significant).

Although we hypothesized in our fifth hypothesis that the consequences perceived in relation to palm oil would motivate consumers more to seek information about it, we 
have demonstrated this effect precisely for the risks perceived in general. That is, even though respondents know little about the effects of palm oil, they tended to start looking for information when they perceived one of the three consequences in general.

\section{Discussion}

In our study, we explored consumer knowledge about the three consequence typeshealth, environmental, and social-associated with palm oil, and we assessed the perceptions of these risks. In addition, we used structural equation modeling to examine whether the three risk types had a stronger effect on palm oil-avoiding behavior if they were perceived in general or specifically in association with palm oil.

Of the three outcome types, respondents thought they were the least familiar with social risk, and the most familiar with environmental risk. Only a small proportion of respondents considered the examined palm oil-containing products to be healthy.

Our research is one of the first to examine the purchase intent for palm oil-containing products with the method of structural equation modeling, through the three consequence types associated with palm oil. Information seeking and consumer personal beliefs about palm oil are also included in our model. The addition of this latter element proved to be extremely important in exploring the factors influencing purchase intent for palm oil-free products. All three associated consequences influenced consumers' palm oil-avoiding behavior, but a defining aspect is whether we examined a general or a palm oil-specific risk. The health and environmental outcomes associated specifically with palm oil had a direct effect on purchase intent, while the environmental and health risks perceived in general had an effect only through the mediation of information seeking. In the case of social risk, the model shows the opposite.

Although previous research revealed that the environmental and health effects of palm oil influenced consumers in their purchase intent related to palm oil $[14,18,19]$, our results show that these factors only affect consumers if they perceived them specifically in the context of palm oil. Based on our model, the general and palm oil-specific risk (total effect) that has the strongest influence on palm oil-avoiding consumer behavior is the health risk.

\section{Conclusions}

Palm oil is the most-used vegetable oil used in the greatest amount in the world, and it is also used in the food industry in many ways due to its beneficial technological properties. At the same time, the production, processing, and consumption of palm oil have brought about consumer resentment. Our research aim was to assess which palm oil-related consequence, whether health, environmental, or social, influenced the purchase intention to buy palm oil-free products the most.

Based on our results, it has market relevance that a food processing company offering palm oil-free products communicates this product feature to consumers. This is because communicating palm oil-freeness gives consumers the opportunity to reduce the negative consumer feelings associated with the production, processing, or consumption of palm oil. Given the importance of the health consequence, palm oil-free products should be positioned among the healthier foods. The communication of individual consequences can be an important part of the communications of companies developing palm oil-free products, but it matters which consequences are mentioned. It is important to assess which general consequence concerns their target group the most: if it is the health or environmental consequence, then the consumer might be made aware either that the potentially harmful health effects of this ingredient can be avoided or that it is more ecofriendly than its palm oil-containing counterparts. As a result of such a statement, these consumers may already begin to gather more information about palm oil. However, if it is the social risk, then consumers could be motivated to gather information about such effects of palm oil production, because it has an impact on consumer behavior only indirectly, through information seeking. 


\section{Limitations and Further Research}

Although the explanatory power of the model is already quite high for consumer research (adjusted $R^{2}=0.597$ ), further research should explore other factors that may influence consumers, for example by including the elements of the theory of planned behavior [53] or the food-related lifestyle model $[54,55]$ and expanding on the model.

Our results suggest that it would benefit food processing companies to place palm oil-free information or a logo on their products. However, the importance of such a sign is questionable in an over-communicated environment where consumers already have to consider a number of factors on the packaging [56]

Our research does not separately address the perception of palm oil coming from sustainable sources. It would be worthwhile to examine it with the factors influencing purchase intention used in the present study.

Our study is not based on a representative sample, so further research should test the model on such a sample, too. Also, our sample was limited to one country, and it would be important to investigate the importance of the individual factors in an international comparison.

Author Contributions: Conceptualization, B.P. and Á.T.; methodology, B.P. and Á.T.; formal analysis, B.P.; investigation, B.P.; writing—original draft preparation, B.P.; writing—review and editing, Á.T., Z.L.; visualization, B.P.; supervision, Á.T.; project administration, K.B.-K., A.K.; funding acquisition, K.B.-K. All authors have read and agreed to the published version of the manuscript.

Funding: The Project is supported by the European Union and co-financed by the European Social Fund (grant agreement no. EFOP-3.6.3-VEKOP-16-2017-00005) and supported by the ÚNKP-20-3-II New National Excellence Program of the Ministry for Innovation and Technology from the source of the National Research, Development and Innovation Fund.

Informed Consent Statement: Written informed consent was obtained from all subjects involved in the study.

Data Availability Statement: The data presented in this study are available on request from the corresponding author.

Conflicts of Interest: The authors declare no conflict of interest.

\section{References}

1. Shahbandeh, M. Consumption of Vegetable Oils Worldwide from 2013/14 to 2019/2020. By Oil Type (in Million Metric Tons). Available online: https:/ / www.statista.com/statistics/263937/vegetable-oils-global-consumption/ (accessed on 28 May 2020).

2. Shahbandeh, M. Production Volume of Palm Oil Worldwide from 2012/13 to 2019/20 (in Million Metric tons). Available online: https:/ / www.statista.com/statistics/613471/palm-oil-production-volume-worldwide/ (accessed on 28 May 2020).

3. Reardon, K.; Padfield, R.; Salim, H.K. “Consumers don't see tigers dying in palm oil plantations”: A cross-cultural comparative study of UK, Malaysian and Singaporean consumer views of palm oil. Asian Geogr. 2019, 36, 117-141. [CrossRef]

4. Rival, A.; Levang, P. Palms of Controversies: Oil Palm and Development Challenges; CIFOR: Bogor, Indonesia, 2014.

5. Magyar Közlöny. Az emberi erőforrások minisztere 71/2013. (XI. 20.) EMMI rendelete az élelmiszerekben lévő transz-zsírsavak megengedhető legnagyobb mennyiségéről, a transz-zsírsav tartalmú élelmiszerek forgalmazásának feltételeiről és hatósági ellenőrzéséről, valamint a lakosság transz-zsírsav bevitelének nyomon követésére vonatkozó szabályokról. Magy. Közlöny 2013, 22-23. Available online: https://net.jogtar.hu/jogszabaly?docid=a1300071.emm (accessed on 28 May 2020).

6. Alliance, E.P.O. Trans Fat Reduction and Replacement in Europe. Available online: https://palmoilalliance.eu/wp-content/ uploads/2019/06/TFA_infographic_website.pdf (accessed on 4 July 2020).

7. Mba, O.I.; Dumont, M.-J.; Ngadi, M. Palm oil: Processing, characterization and utilization in the food industry-A review. Food Biosci. 2015, 10, 26-41. [CrossRef]

8. Berger, K.G. Palm oil. In Structured and Modified Lipids; Marcel Dekker Press: New York, NY, USA, 2001; pp. 119-153.

9. Voora, V.; Larrea, C.; Bermúdez, S.; Baliño, S. Global Market Report: Palm Oil; International Institute for Sustainable Development (IISD): Winnipeg, MB, Canada, 2020; p. 16

10. Hinkes, C.; Christoph-Schulz, I. No Palm Oil or Certified Sustainable Palm Oil? Heterogeneous Consumer Preferences and the Role of Information. Sustainability 2020, 12, 7257. [CrossRef]

11. Borrello, M.; Annunziata, A.; Vecchio, R. Sustainability of palm oil: Drivers of consumers' preferences. Sustainability 2019, 11, 4818. [CrossRef] 
12. Disdier, A.-C.; Marette, S.; Millet, G. Are consumers concerned about palm oil? Evidence from a lab experiment. Food Policy 2013, 43, 180-189. [CrossRef]

13. Hinkes, C.; Christoph-Schulz, I. Consumer attitudes toward palm oil: Insights from focus group discussions. J. Food Prod. Mark. 2019, 25, 875-895. [CrossRef]

14. Lange, F.; Coremans, L. The role of consumer knowledge in reducing the demand for palm oil. Environ. Conserv. 2020, 38, 1-5. [CrossRef]

15. Aguiar, L.K.; Martinez, D.C.; Caleman, S.M. Consumer awareness of palm oil as an ingredient in food and non-food products. J. Food Prod. Mark. 2018, 24, 297-310. [CrossRef]

16. Sodano, V.; Riverso, R.; Scafuto, F. Investigating the intention to reduce palm oil consumption. Calitatea 2018, 19, 500-505.

17. Mukherjee, S.; Mitra, A. Health effects of palm oil. J. Hum. Ecol. 2009, 26, 197-203. [CrossRef]

18. Capecchi, S.; Amato, M.; Sodano, V.; Verneau, F. Understanding beliefs and concerns towards palm oil: Empirical evidence and policy implications. Food Policy 2019, 89, 101785. [CrossRef]

19. Verneau, F.; La Barbera, F.; Amato, M.; Sodano, V. Consumers' concern towards palm oil consumption. Br. Food J. 2019, 121, 1982-1997. [CrossRef]

20. Hartmann, C.; Hieke, S.; Taper, C.; Siegrist, M. European consumer healthiness evaluation of 'Free-from'labelled food products. Food Qual. Prefer. 2018, 68, 377-388. [CrossRef]

21. Khan, M.S.; Saengon, P.; Alganad, A.M.N.; Chongcharoen, D.; Farrukh, M. Consumer green behaviour: An approach towards environmental sustainability. Sustain. Dev. 2020, 28, 1168-1180. [CrossRef]

22. Morales, P.A.; True, S.; Tudor, R.K. Insights, challenges and recommendations for research on sustainability in marketing. J. Glob. Sch. Mark. Sci. 2020, 30, 394-406. [CrossRef]

23. Szakos, D.; Szabó-Bódi, B.; Kasza, G. Consumer awareness campaign to reduce household food waste based on structural equation behavior modeling in Hungary. Environ. Sci. Pollut. Res. 2020, 1-10. [CrossRef]

24. Bangsa, A.B.; Schlegelmilch, B.B. Linking sustainable product attributes and consumer decision-making: Insights from a systematic review. J. Clean. Prod. 2020, 245, 118902. [CrossRef]

25. Boz, Z.; Korhonen, V.; Koelsch Sand, C. Consumer considerations for the implementation of sustainable packaging: A review. Sustainability 2020, 12, 2192. [CrossRef]

26. Elhoushy, S.; Lanzini, P. Factors affecting sustainable consumer behavior in the MENA region: A systematic review. J. Int. Consum. Mark. 2020, 10, 1-24. [CrossRef]

27. Guadalupe, G.A.; Lerma-García, M.J.; Fuentes, A.; Barat, J.M.; Del Carmen Bas, M.; Fernández-Segovia, I. Presence of palm oil in foodstuffs: Consumers' perception. Br. Food J. 2019, 121, 2148-2162. [CrossRef]

28. Corley, R. How much palm oil do we need? Environ. Sci. Policy 2009, 12, 134-139. [CrossRef]

29. Parsons, S.; Raikova, S.; Chuck, C.J. The viability and desirability of replacing palm oil. Nat. Sustain. 2020, 3, 412-418. [CrossRef]

30. Fabbrizzi, S.; Cipollaro, M.; Marinelli, N. The consumer perception of the presence of palm oil in food products: An exploratory study in Italy. Qual.-Access Success 2019, 20, 249-254.

31. Ostfeld, R.; Howarth, D.; Reiner, D.; Krasny, P. Peeling back the label—exploring sustainable palm oil ecolabelling and consumption in the United Kingdom. Environ. Res. Lett. 2019, 14, 014001. [CrossRef]

32. Hinrichsen, N. Commercially available alternatives to palm oil. Lipid Technol. 2016, 28, 65-67. [CrossRef] [PubMed]

33. Bateman, I.J.; Fisher, B.; Fitzherbert, E.; Glew, D.; Naidoo, R. Tigers, markets and palm oil: Market potential for conservation. Oryx 2010, 44, 230-234. [CrossRef]

34. Giam, X.; Mani, L.; Koh, L.P.; Tan, H.T. Saving tropical forests by knowing what we consume. Conserv. Lett. 2015, 9, 267-274. [CrossRef]

35. Sundaraja, C.S.; Hine, D.W.; Lykins, A. Confronting the palm oil crisis: Identifying behaviours for targeted interventions. Environ. Sci. Policy 2020, 103, 99-106. [CrossRef]

36. Ayompe, L.M.; Schaafsma, M.; Egoh, B.N. Towards sustainable palm oil production: The positive and negative impacts on ecosystem services and human wellbeing. J. Clean. Prod. 2020, 278, 123914. [CrossRef]

37. Zhu, W.; Yao, N.C.; Ma, B.; Wang, F. Consumers' risk perception, information seeking, and intention to purchase genetically modified food: An empirical study in China. Br. Food J. 2018. [CrossRef]

38. Grasso, K.L.; Bell, R.A. Understanding health information seeking: A test of the risk perception attitude framework. J. Health Commun. 2015, 20, 1406-1414. [CrossRef]

39. Kellens, W.; Zaalberg, R.; De Maeyer, P. The informed society: An analysis of the public's information-seeking behavior regarding coastal flood risks. Risk Anal. Int. J. 2012, 32, 1369-1381. [CrossRef] [PubMed]

40. Cerri, J.; Testa, F.; Rizzi, F. The more I care, the less I will listen to you: How information, environmental concern and ethical production influence consumers' attitudes and the purchasing of sustainable products. J. Clean. Prod. 2018, 175, 343-353. [CrossRef]

41. Ringle, C.M.; Wende, S.; Becker, J.-M. SmartPLS 3. Boenningstedt: Smartpls. 2015. Available online: http:/ /www.smartpls.com (accessed on 1 June 2020).

42. Cortina, J.M. What is coefficient alpha? An examination of theory and applications. J. Appl. Psychol. 1993, 78, 98. [CrossRef]

43. Hair, J.F.; Ringle, C.M.; Sarstedt, M. PLS-SEM: Indeed a silver bullet. J. Mark. Theory Pract. 2011, 19, 139-152. [CrossRef] 
44. Hair, J.F.; Risher, J.J.; Sarstedt, M.; Ringle, C.M. When to use and how to report the results of PLS-SEM. Eur. Bus. Rev. 2019. [CrossRef]

45. Bagozzi, R.P.; Yi, Y. On the evaluation of structural equation models. J. Acad. Mark. Sci. 1988, 16, 74-94. [CrossRef]

46. Hulland, J. Use of partial least squares (PLS) in strategic management research: A review of four recent studies. Strateg. Manag. J. 1999, 20, 195-204. [CrossRef]

47. Hair Jr, J.F.; Hult, G.T.M.; Ringle, C.; Sarstedt, M. A Primer on Partial Least Squares Structural Equation Modeling (PLS-SEM); Sage Publications: Thousand Oaks, CA, USA, 2017.

48. Hu, L.t.; Bentler, P.M. Cutoff criteria for fit indexes in covariance structure analysis: Conventional criteria versus new alternatives. Struct. Equ. Modeling A Multidiscip. J. 1999, 6, 1-55. [CrossRef]

49. Marsh, H.W.; Hau, K.-T.; Wen, Z. In search of golden rules: Comment on hypothesis-testing approaches to setting cutoff values for fit indexes and dangers in overgeneralizing Hu and Bentler's (1999) findings. Struct. Equ. Modeling 2004, 11, 320-341. [CrossRef]

50. Bentler, P.M. Comparative fit indexes in structural models. Psychol. Bull. 1990, 107, 238. [CrossRef] [PubMed]

51. Fornell, C.; Larcker, D.F. Evaluating structural equation models with unobservable variables and measurement error. J. Mark. Res. 1981, 18, 39-50. [CrossRef]

52. Henseler, J.; Ringle, C.M.; Sarstedt, M. A new criterion for assessing discriminant validity in variance-based structural equation modeling. J. Acad. Mark. Sci. 2015, 43, 115-135. [CrossRef]

53. Ajzen, I. The theory of planned behavior. Organ. Behav. Hum. Decis. Process. 1991, 50, 179-211. [CrossRef]

54. Brunsø, K.; Birch, D.; Memery, J.; Temesi, Á.; Lakner, Z.; Lang, M.; Dean, D.; Grunert, K.G. Core dimensions of food-related lifestyle: A new instrument for measuring food involvement, innovativeness and responsibility. Food Qual. Prefer. 2021, 104192. [CrossRef]

55. Grunert, K.G.; Brunsø, K.; Bredahl, L.; Bech, A.C. Food-related lifestyle: A segmentation approach to European food consumers. In Food, People and Society; Springer: Berlin/Heidelberg, Germany, 2001; pp. 211-230. [CrossRef]

56. Kaczorowska, J.; Prandota, A.; Rejman, K.; Halicka, E.; Tul-Krzyszczuk, A. Certification Labels in Shaping Perception of Food Quality-Insights from Polish and Belgian Urban Consumers. Sustainability 2021, 13, 702. [CrossRef] 